\title{
Cleopatra's Autonomy as Ruler of Ptolemy Egypt and the Examination of the Roman Influence Over Egypt
}

\author{
Shuoheng Huang* \\ Shenzhen College of International Education, Shenzhen, Guangdong 518043, China \\ *Corresponding author. Email: s19039.huang@stu.scie.com.cn
}

\begin{abstract}
As the last ruler of Ptolemy Dynasty, Cleopatra VII was frequently accessed either from her methods of governing or her controversial affairs. This paper will mainly discuss Cleopatra's level of independence as the Ptolemy monarch during the transition from Roman Republic to Roman Empire. Overall, Cleopatra was an influential figure who managed to secure the strongest relationship between a Ptolemy and a Roman leader. However, the strategic concerns of Rome destined the doom of herself and her empire. In this work, the fall of Ptolemy Empire is intended to be placed under a wide international spectrum, where a single historical event is compared, paralleled and evaluated aside from the indispensable impact of foreign intervention.
\end{abstract}

Keywords: Cleopatra VII, Ptolemy, Caesar, Antony, Rome

\section{INTRODUCTION}

Thanks to the 1963 Hollywood film Cleopatra, the legendary story of probably the most fascinating woman in ancient history again revitalizes on the modern spectrum. Cleopatra VII, the second daughter of Ptolemy XII, was the last ruler of the Ptolemaic Dynasty [1]. Her historical significance was surprisingly ignored and largely misunderstood, especially considering she was the only woman in the classical world to rule independently and not merely as a successor of her dead husband [2]. This paper will examine the political structure of the late Ptolemy Dynasty and its problematic relationship with Rome. It will also evaluate Cleopatra's power and impact on the Egyptian military and politics. It will measure her multiple talents as well. Moreover, an in-depth examination will be taken on two leading Romans and how they each affected Egypt and Cleopatra. Restrained by time and other factors, this paper failed to analyze the correlation between Egypt and other countries in the Asian Minor. Further research on this area can be centred around the geopolitical determinants that influenced the decision-making of nonRoman states in the Eastern Mediterranean. Economic or economic history analysis on the late Ptolemy Empire could as well hold great research value.

In general, Cleopatra only had minor autonomy in ruling Egypt, despite her brilliance as a competent ruler and excellence as a late queen.

\section{PTOLEMY IN 69 BCE}

\subsection{Ptolemies: Declining Royals}

To begin with, Ptolemy Empire's obsolete governing system and its fixed traditions contribute significantly to its recession up until the reign of Cleopatra. Surprisingly, the vast empire in which most of its authority centred around Egypt was not ruled by native Egyptians. Instead, it was governed by Macedonian-Greeks. In 323 BCE, Ptolemy I, general and companion of the Great Macedonian king Alexander IV, proclaimed his sovereignty over Egypt [1]. Forty years later, when Ptolemy II ascended to the throne, an unprecedented royal custom was set through a brother-sister marriage between himself and his sister Arsinoe II [1]. This controversial tradition would pass along generations as the sole cohesion of Ptolemies' dominance. Obeying such tradition, Cleopatra was first appointed by the Alexandrians co-ruler with her brother-and-husband Ptolemy XIII [3]. For nearly 300 years of ruling, the Ptolemy kingdom scarcely carried out any reforms. It was regents or eunuchs who were often in charge of ruling as the brother-sister marriage tradition generate heirs that were too young to rule. This arrangement provides room for significant political turbulence. The conflicts between Ptolemy VII and his brother Ptolemy VIII gave birth to an unprecedented will to name Rome as the legitimate heir of Kyrene (more in next chapter). 
Therefore, it can be concluded that Ptolemaic Egypt was a Hellenistic kingdom with a monarch regime that was biologically preserved by family inbred between brothers and sisters. This unique or probably disputable structure eventually and definitely facilitated the diversion of political factions, causing Egypt bothered consistently by internal conflicts.

\subsection{Ptolemaic-Roman Relationship}

Before examining the Egyptian relationship with Rome when Cleopatra took power, we must first acknowledge how these two empires crossed with each other. Their first contact came in 273 BCE when Ptolemy II sent an embassy to Rome to congratulate the Senate's latest victory over Epirus. Egyptians managed to retain a relatively positive relationship with their western neighbour during Ptolemy II's reign. Such friendship eventually favoured the Romans and focused on fighting the Carthaginians without worrying about Egyptian intervention. This sweet period between the two nations did not hold long, though. During the rules of Ptolemy V, Egyptians were pressured by the Seleucid king Antiochus III's grand victory over Coele-Syria. A separate peace was drawn through the marriage of young Ptolemy V and Antiochus's daughter Cleopatra I [1]. This is presumably the first time the name "Cleopatra" enters history as the daughter of another Macedonian king. The unheralded marriage marked a significant downturn of Ptolemaic-Rome relationship, as the Romans found themselves concealed from their once good neighbours. Although Stanley Burnstein (2004) concluded, in his brilliant work The Reign of Cleopatra, that the fundamental driving force behind Rome's growing intervention in Egypt was a reasonable suspicion due to its increasingly dominant power, it is still worth pointing that the Ptolemy emperors had never shown their dissatisfaction or plotted any rebellion against the rising Mediterranean overlord. Therefore, it might seem a bit inattentive to blame Roman's initiatives simply for its premature ambitions. The real incentives behind Rome's sudden grip on its eastern fellow went unmentioned in any primary sources. That is to say, merely blaming the desperate regents of Ptolemy V and their thoughtlessness in establishing an uninformed marriage was simply unfair for the diligent Ptolemy rulers. We must not ignore Antiochus III's own military and political brilliance and how his ability imposed heavy pressure on the Ptolemy rulers. No matter what the initiatives were, the freedom of a self-governed Ptolemy Egypt eminently declined, and its reliance on the expanding Roman power incremented ever since.

Such reliance later converts into a written contract that presumably possessed formal legal effectiveness. An inscription was found in Kyrene (SEG 9.7), indicating that the secluded king Ptolemy VIII named Rome as his heir after his death. Romans would soon make an issue over this specific will. When Caesar readout Ptolemy XII's will at an Egyptian assembly, proclaiming himself to be the guardian of the two co-rulers [3], it was precisely Ptolemy VIII's will that endowed him this right. The Roman-Ptolemaic connection had then evolved into a legal bonding, making the Roman Senate, not merely consultants and mediators of Egypt but the legitimate successor of significant Ptolemaic territory. Therefore, the power balance between a dominant Mediterranean nation and a declining dynasty had shifted in Roman's favour. This increasingly dependent tendency would later escalate during the reign of Cleopatra's father, Ptolemy XII.

After the establishment of legal bonds, the Egyptians then involve themselves in a debtor-creditorship with leading Roman figures. In $63 \mathrm{BCE}$, Ptolemy XII tried to offer many advantages to Pompeius in return for Roman advocation of his legitimate rule [4]. However, historians didn't seem to clarify the exact list of presents offered by Ptolemy XII. In his sensational Natural History, Pliny suggests that only 8,000 horses were sent to assist Pompey's campaign over Judaea [5], while modern historians tend to believe another golden crown was presented as flattery to show their determination [2]. This act of lavishly entertaining a Roman leader marked Egyptian interactions with Rome in financial aspects. The front of economics exchange marched to its peak when Julius Caesar, long before his fascinating encounter with Cleopatra, demanded a massive bribe from Ptolemy XII. This attempt was accounted in Suetonius's biography of Julius Caesar as "He sold alliances and thrones for cash, making Ptolemy give him and Pompey nearly 6,000 talents" [6]. The outcomes of such bribery, fortunately, went in the king's favour. The First Triumvirate readdressed him as a friend and ally of the Roman people and the rightful king of his nation. Nevertheless, Ptolemy's immoderate spending in domestic affairs forced him to borrow large sums of money in Rome. His debtors included Crassus and Postmus [2]. In his excellent recount of A History of the Ptolemaic Empire, Hölbl asserted the reasons behind Ptolemy XII's massive bribery were primarily due to a desperate campaign to ensure that the dynasty would continue to exist instead of being annexed by Rome [4]. It is almost certain that his extravagant ruling both domestically and abroad pushed the kingdom into an even more dependent relation with Rome. The act of extorting the Egyptian treasury absolutely exhausted their finance. Entering the 50s BCE, Rome became not only a legitimate successor with Ptolemy Egypt but also its largest creditor.

At this point, the Senate was able to curb Egypt's financial artery. Burdens from Rome had become increasingly unbearable for the incumbent Ptolemy XII. His act to secure his throne would soon backfire on himself and Cleopatra. 


\subsection{Storm in Formation: Domestic Conflicts in $50 \mathrm{BCE}$}

Ptolemy XII left his children in an alarming situation. As a result, Cleopatra would have to face tremendous obstacles from within the nation when she sought dominance in the co-ruling relation with her brother. In the early 50s, the gigantic liability with Rome had to be compensated by increasing taxation on average Egyptians [4]. However, as Egypt was an agriculturaldominant country with most of its people living along the River Nile, discontent from farmers or local Egyptians didn't seem to cause much disturbance. The real trouble came from political resistance in Alexandria. Cleopatra's high-key actions drew dissatisfaction from the faction that backed her brother. The exact split between the ruling Ptolemy XII and his Alexandrian-Greek loyalists led to his exile. In Cleopatra's situation, Potheinos, a leading eunuch of the young Ptolemy XIII, posed the queen's greatest counteractions. Although the same excuse the thirteenth Ptolemy proposed on expelling his sister was unclear, it seemed clear that Cleopatra was overpowered by such faction in 50/49 BCE. Cleopatra's absence could only be shown from an edict of October 27 with only her brother's affix and the attempt to set up a dating system based on Ptolemy XIII's reign [4]. Since the king was only 12 years old at the time, it's reasonable to infer that Potheinos was the sole plotter behind these major actions, which extended from expulsing Cleopatra out of power and ambushing the fleeing Pompey. The first few years of Cleopatra's governance were not in her favour. Several famines stroked native farmers along the Nile. The massive debt owed to Rome was also depleting the Egyptian economy. A total number of 17.5 million drachmas, according to Plutarch, was still unpaid when Caesar arrived in Alexandria in the early 40s [7].

Despite the financial strains, Cleopatra also had to face severe opposition from her brother's faction. When Cleopatra inherited the reign from her father, Ptolemy Egypt was already at the edge of boiling. The room for her own declaration of power was little. Therefore, having experienced several crises since Ptolemy X's reign, Ptolemy Egypt was then feeble. Ptolemy XII handed his daughter a rotten legacy. However, what made Cleopatra such a prominent figure in classical antiquity was precisely her ability to overturn such chaos. Her unique combination of talents as a ruler will be examined in the following chapter.

\section{QUEEN OF MAGNIFICENCE}

\subsection{Army in Cleopatra's Command}

Cleopatra was neither a general gifted with great military talents nor a ruler maniacal to military conquest. Unlike most of her predecessors, Cleopatra faced small obstacles from her eastern neighbours. She even seldom commanded an army throughout her entire career. The two most prominent military actions Cleopatra led were her attempt to resecure the throne in $48 \mathrm{BCE}$ and the final Armageddon against Caius Octavian. The two battles, coincidentally, happened at the beginning and end of her reign. This section will examine the military power Cleopatra possessed as queen of Egypt and evaluate whether her army made her a sufficient candidate against foreign intervention.

In 49/48 BCE, Cleopatra and her supporters were outcasted by her brother's faction. Details of this political struggle can be found in the previous chapter. Strabo accounted that Cleopatra set her sails to Syria, seeking help from the local royals [8]. How and when she summed her mercenary army was unknown. Nevertheless, historians have provided reliable speculations behind the Syrian's motives. The long-term loan relationship between the Syrian and Cleopatra's father may be one of the determining factors. No matter how Cleopatra acquired that army, her gigantic comeback definitely shocked Ptolemy XII's supporters. The young king, along with his regents Potheinos and Achillas (the Egyptian general who killed Gnaeus Pompey), set up frontiers at Pelusium, the eastern stronghold in lower Egypt nervously waited for Cleopatra's arrival [9]. This was the first time the queen had manifested her intimidating military power. However, when she heard that Julius Caesar was in Alexandria and was calling for a meeting to settle for peace, she immediately decided to abandon her troops, sneaked undignifiedly through Achillas's blockade, and presented herself, as countless later generations would portray with cut and dry, in front of the great Julius Caesar. Therefore, the initial attempt to examine Cleopatra's military ability failed as she never went to war with her army. Her ability to wage a sufficient army in a short period of time was embodied in this action. As for how good she was as a commander or how welltrained her Philistine-origin soldiers were, no conclusions can be drawn. Still, Cleopatra demonstrated her great popularity and diplomatic influence at such a young age.

The other and final major warfare fought by Cleopatra was the legendary Battle of Actium, in which she failed, lost her lover, soon killed herself as the entire Ptolemy kingdom buried with her. But long before her final failure, Cleopatra did reveal her potential to be an eligible commander. By the year $31 \mathrm{BCE}$, civil conflicts between Octavian and Antony had formally transformed into a full-scale war between Rome and Ptolemy Egypt. In order to protect Egypt against Octavian's invasion, Cleopatra built a defensive belt from Kyrene to the Ionian Sea [4]. Cleopatra's ability to bring out a practical war plan could be seen from this action. When Octavian's remarkable general Agrippa enforced a naval blockade against Antony's chief forces in the Gulf of Actium, Cleopatra also voted in the war council 
supporting a breakthrough. Her own vessels managed to break past Agrippa's lockdown and safely disembarked in Alexandria. Whereas Antony, entangled in a heated engagement that caused severe casualties, was deemed to lose this war after his infantry mutinied to the opposite side [4]. It was no doubt that Cleopatra proved her military instinct by unhesitatingly breaking out enemy blockades with force and speed vessels. However, the Battle of Actium was not fought by Cleopatra's own Egyptian army. Antony's soldiers played essential parts for both sides in this war. Even at the most intense moment of her kingdom, the queen did not fully control an army good enough to protect her reign. But her military ability could not be ignored, for she had indeed made several crucial actions. It is, therefore, reasonable to infer that, if given with enough army and taking the upper hand, Cleopatra should have the power to at least continue warfare rather than immediately losing it.

Another interesting fact regarding Cleopatra's military career was she waged these major wars at the beginning and end of her reign, respectively. This, therefore, suggested that she was the indisputable representative of Egypt throughout her 17/18 years of incumbency, and her governance was never fatally challenged. In conclusion, the military power of Cleopatra was no match for the Roman forces. However, such power could still deter her rivals within Egypt. Cleopatra's military career, therefore, revealed more of her ruling stability rather than her significance at war.

\subsection{Queen of Socializing}

Throughout history, Cleopatra was often portrayed as an evil figure who had bewitched every man she encountered. Fiction writers and pop culture composers falsely valued her sexuality over her historical significance. These impressions are mainly misleading and exaggerated, for she was a woman with spectacular capability. Cleopatra was a competent ruler who received premium education, even for one of the royals in her youth.

She was often slandered for her first appearances before Caesar and Antony, which was simply unfair. Ancient historians, on the other hand, seemed to agree on different aspects of her unique charm. Plutarch mainly addressed her alluring voice and her talents to speak multiple languages in his Life of Antony, suggesting she was an expert in catching her audience:

It was a pleasure merely to hear the sound of her voice, with which, like an instrument of many strings, she could pass from one language to another... to most of them she spoke herself, as to the Ethiopians, Troglodytes, Hebrews, Arabians, Syrians, Medes, Parthians, and many others, whose language she had learned; which was all the more surprising, because most of the kings her predecessors scarcely gave themselves the trouble to acquire the Egyptian tongue, and several of them quite abandoned the Macedonian [10].

Another prominent historian Cassius Dio accounted for her astonishing beauty when she presented herself to Julius Caesar. Dio as well mentioned her incredible ability to persuade her audience:

For she was a woman of surpassing beauty, and at that time, when she was in the prime of her youth, she was most striking; she also possessed a most charming voice and a knowledge of how to make herself agreeable to everyone [3].

Dio and Plutarch both lived centuries after Cleopatra's time. Therefore, their work could be considered a combination of first-hand sources and the prevailing opinion of Cleopatra. Neither of them met the queen in person. But both of them maintained a relatively neutral stand while the primary propaganda depicted Cleopatra as a snack-like villain [4]. Dio and Plutarch's work substantially illustrated why she attracted two of the most remarkable Romans of all time at different stages of her life. She was humorous, beautiful, sensitive to people's inner needs, and knew exactly how to gain her advantage over them. In many ways, she very much resembled Julius Caesar. They were both great orators, taught by some of the most eminent public speakers of their time; they were both masters at negotiation and bargaining; they both generated scandalous gossips that, though never verified, were primarily based on their luxurious lifestyle. It was therefore unbelievable for Cleopatra to manifest such maturity and scheme at the tender age of eighteen. No matter how historians from the imperial period insulted her, Cleopatra's significance could never be shrouded.

\section{CLEOPATRA AND HER ROMAN PARTNERS}

\subsection{Motives Behind Roman Annexation}

Before getting into the fascinating stories of Caesar and Antony, it shall be addressed that for what and how were the Romans so attracted to Egypt. Egypt at Ptolemaic governance yields a massive number of grains. The Ptolemies had introduced new crops and advanced cultivation technologies to acquire tremendous grain surplus after sustaining their entire population [11]. The banks of the Nile were also prolific in minerals such as gold, salt, and limestones. Its fertile lands further stimulated the growth of Alexandria as Egypt's main harbour. With a land of myriad wealth and resources, every Egyptian ruler, including Cleopatra, benefitted from its fortune while also worried about the foreign predators that coveted such treasure. Rome was no exception. Its considerable wealth was the most significant motive behind Roman's successive controls over Egypt. Julius Caesar sought to take back his loans 
while discovering Egypt's potential as an eastern military base as well as a giant granary. Antony needed Egypt's influence over the east Mediterranean to win the Parthian War. On the other hand, Cleopatra knew very well the importance of playing this double blade between herself and Rome. As it will be discussed in the following text, all of Cleopatra's annexation and Roman's actions were based on this essential condition: resource.

For all Ptolemaic rulers before Cleopatra, none had managed to achieve such compact and friendly relations with Rome as she did. Cleopatra was the first Egyptian ruler to establish a personal relationship so tight with Roman leaders that she, by all means, earned herself shares of Roman power. Though her actions were often judged, her relation with Caesar and Antony did, to a large extent, realized many of her proposals. Her achievements and failure regarding this dedicated Ptolemaic-Roman honeymoon.

\subsection{Julius Caesar}

At the age of 52, the great Julius Caesar met the young queen of Egypt. His mysterious relationship with Cleopatra never stopped grabbing historians' attention. Nonetheless, despite the intriguing and sometimes misleading stories, Cleopatra and Caesar's relation was primarily based on common interests. It seemed obvious in 48 that Caesar would win his Civil War after winning the decisive battle of Pharsalus. As Pompey was slain by regents of Ptolemy XIII near Pelusium [12], Caesar no longer had any rival in the Mediterranean world. This man of invincibility, however, met some obstacles during his temporary stay in Egypt. Caesar accounted for much detail about his military campaign in Egypt in his Bellum Alexandrinum. In short, Caesar executed the eunuch Potheinos; Ptolemy XIII was drowned in a chaotic retreat; Achillas, the general who killed Pompey, was plotted and killed by Arsinoe's regent Ganymede [9, 13]. Caesar's arrival undoubtedly stabilized Egypt's domestic turbulence and eventually secured Cleopatra's dominance.

Like all Roman leaders, Caesar as well valued the wealth of Egypt. He might even wish to take back his loans offered to Ptolemy XII (more on this liability, see page 7). But he was also very cautious, for good reasons: Egypt was a land so rich that Caesar would fear that transforming Egypt into a Roman province would endow any Roman magistrate the power to revolt. From hindsight, Octavian also discovered this downside and ingeniously resolved this issue by naming himself as the Egyptian magistrate. All in all, Caesar needed Egypt to exist as major agriculture and financial supplier for Rome. This being his purpose, an obedient Egyptian ruler just like Cleopatra had manifested would largely favour his campaign.

Meanwhile, Cleopatra was outcasted by her brother's faction and was waging war to reclaim her throne. She was desperate to have Roman help protect the throne and their formal recognition from securing her position. The situation was, by the year 48, that Cleopatra and Caesar could each take what they needed if they align with one another.

The eminent story of how Cleopatra "presented" herself in front of the most powerful man on earth was always debatable. This paper will not go into the details of this meeting as many of its popular elements, such as Cleopatra hiding in a bed scroll was inaccurate and required a great deal of verification. But there was one thing in particular that puzzled later historians: did Cleopatra conceive Caesar's child in this meeting, who was later named "Ptolemy Caesarion" and became Caesar's rightful heir? The only recognized offspring of Caesar was Julia. She was born in 73 B.C [14]. Considering that Caesar had not produced any children for 25 years (73-48 BCE), whether his fertility was still sufficient enough to give birth to another child was doubtful (R. Billows, personal communication, July 29, 2021). However, on many occasions, Cleopatra and later Antonius would proclaim this child as Caesar's son, the King of Kings [1]. Therefore, it is reasonable to infer that bearing Caesar his son, or at least she claimed so, was only one of Cleopatra's methods to secure her relationship with Rome. Cleopatra would then give birth to three of Antony's children obeying this same method [9]. No one in Ptolemaic history had ever born heirs of their Roman patrons. Cleopatra became the first to establish a blood-tie or family relation with Roman leaders.

Examining her action from a different perspective, Cleopatra's influence over Roman leaders did not fully relieve her. Her outpowered position was precisely why she had to progress further with the Romans in a less conventional and more disputable way.

\subsection{Marcus Antonius}

Late in her reign, Cleopatra performed her boldest move against Roman politicians. By annexing with Marcus Antonius, who was one of the Second Triumvirate and the sole leader of the Caesarians, Cleopatra had an influential Roman leader in her alliance. Cleopatra's relationship with Antony was tighter, emotionally more vigorous, and unquestionably more tragic than Julius Caesar's. Her close relation with Antony precisely illustrated her helplessness in front of Roman authorities. Such relation, portrayed in various works of literature throughout history, eventually led to the death of Cleopatra and the doom of the Ptolemaic Dynasty.

Just like with Caesar, Cleopatra built the relation with Antony based on a political alliance. The Second Triumvirate was formed between Caesar's most 
prominent supporters: his general Mark Antony, his adopted son and heir Octavian, and his supporter Lepidus. The Triumvirate had united to eliminate Caesar's assassins - Brutus and Cassius [15]. Another Roman Civil War broke out between the Caesarians and anti-Caesarians. Considering her previous experience, Cleopatra naturally took Caesarian's side. As Cassius occupied Syria and formed an alliance with the king of Parthia, the triumvirate realized the value of Egyptian help. In order to gain Cleopatra's support, the triumvirs' general and representative Dolabella agreed to recognize Caesarion as Egypt's co-ruler. In return, Cleopatra would offer them four legions to fight in Syria [9]. Antony needed Egypt's resources and support to help him win the war over the Parthians, while Cleopatra needed the assistance of leading Roman figures to solidify her power [16]. The status quo was just like the one with Julius Caesar: both sides saw the potential in this relationship, so both decided to advance it.

Antony was found of, just like his predecessor Caesar, oriental luxuries [10]. This was the exact weakness Cleopatra focused on exploiting. In their renowned meeting in Tarsus, Cleopatra manifested her wealth and astounding beauty in an incomparable way which swiftly captivated the 40-year-old Antony [10]. Her actions to entirely seizure Antony by her feminine charm and spectacular flattery subdued precisely on Antony's vanity and desire. It was, therefore, Cleopatra's closest time to fuse herself with the Roman authorities.

But the reality turned out to be disastrous for Cleopatra. Following the obscurity of Lepidus, the Second Triumvirate had formally transformed into a polarized situation: Octavian controlled the west, Antony controlled the east. Octavian soon waged a propaganda war against Antony and Cleopatra. Antony was so fond of Cleopatra that he intended to divorce his wife, sister of Octavian, Octavia [9]. His imprudent action eventually wrecked the last connection between himself and Octavian, just like the death of Julia and the irreparable relation between Pompey and Caesar. Octavia was a revered lady in Rome. Antony's remarriage with Cleopatra, therefore, violated Roman traditions and drew him great domestic discontent. Such antagonism between Antony and Octavian eventually forced Octavian to retreat to the east. After the decisive Battle of Actium, the tragic lovers met their deaths.

Cleopatra's final attempt to annex Mark Antony ultimately brought her self-destruction. However, this bond with Antony was more intense than ever. Cleopatra managed to establish the tightest relation with a Roman leader for an Egyptian ruler, only to find herself just the opposite. Therefore, it can be concluded that Rome in the 30s BCE was so integral and powerful that no individuals could succeed in acting against Roman interests. For Antony, divorcing Octavia, marrying Cleopatra, annexing Egypt in person, and threatening the rule of
Octavian were just the opposite of Roman interest. Meanwhile, full-scale take-over of Egypt by turning it into a Roman province soundly satisfied the Romans. There it came to the collapse of a 300-year-old Macedonian-origin dynasty. It was unfortunate for Ptolemy Egypt to stand on the route of Roman expansion. Cleopatra, though she tried in numerous efforts and earned herself supports from some of the most significant Roman leaders, could do nothing to stop the pace of Roman expansion.

\section{CONCLUSION}

In conclusion, Cleopatra was not an independent ruler, despite her excellence and outstanding effort to save her country. Although Cleopatra controlled the wealthiest land in the Mediterranean, was equipped with arms forces, and possessed extraordinary talents in various aspects, Romans by the time were too strong for any individual state to deal with. Not to mention her predecessors had left her with a troubling legacy. Therefore, the downfall of Egypt was the inevitable outcome of Roman expansion, and Cleopatra could do little to overturn this. By the time Egypt was merged, the Romans had gone to an imperial path with no turning back.

Cleopatra was a woman of tragedy. She fought for independence throughout her life but was sullied for her actions over centuries. Not until recently did scholars start to justify her efforts. However, there is still a long way to remedy this slandered queen, and these redemptions required the endeavour of many more historians.

Under the sheer time frame available, this paper has many limitations. It failed to enlist the domestic measures Cleopatra took in her reign, as well as a more detailed analysis of Octavian and Pompey's Egypt actions. Further research on this topic could focus more on the horizontal comparison between the fates of different eastern countries during Roman expansion. Also, analysis on Cleopatra from a more psychologist or parental standpoint could be interesting.

If this paper contributes only minorly to the broad field of ancient history and Egyptology, it shall fulfil its purpose.

\section{REFERENCES}

[1]. Burnstein, S. (2004). The Reign of Cleopatra. Greenwood Press, London. pp. 3-29

[2]. Roller, D. W. (2010). Cleopatra: A Biography. Oxford University Press, New York. pp. 2-21

[3]. Dio, Cassius; Cary, E. (1914). Roman History, 42.35. Harvard University Press, New York.

[4]. Hölbl, Günther. (2001). A History of the Ptolemaic 
Empire. Routledge, New York. pp. 224-249

[5]. Pliny; Rackham, H. (1961). Natural History (Book 33-35), 33.138. Harvard University Press, New York.

[6]. Suetonius. (2007). The Twelve Caesars: Divus Julius, 54. Penguin Group, London.

[7]. Plutarch. (2012). Life of Caesar, 48. Start Publishing LLC, New York

[8]. Strabo; Jones, H. L. (1967). Geography, 17.797. Harvard University Press, New York.

[9]. Tyldesley, J. (2008). Cleopatra: Last Queen of Egypt. Profile Books LTD, London. pp. 49-174

[10].Plutarch. (2012). Life of Antony, 25-26. Start Publishing LLC. New York

[11].Editors of Encyclopedia Britannica. (Sep 12, 2003).
Government and conditions under the Ptolemies. https://www.britannica.com/place/ancientEgypt/Government-and-conditions-under-thePtolemies\#ref22346

[12].Plutarch. (2012). Life of Pompey, 79. Start Publishing LLC, New York.

[13].Caesar, Julius. (1967). The Civil War, The Alexandrian War, 31. Penguin Group, London.

[14].Hornblower, S; Spawforth, A. (1999). The Oxford Classical Dictionary, 776. Oxford University Press, Oxford.

[15].Scullard, H. (2010). From the Gracchi to Nero: A history of Rome from 133 B.C. to A.D. 68, 133. Taylor \& Francis Group, Oxfordshire.

[16].Jones, P.J. (2006). Cleopatra: A Source Book, 94. University of Oklahoma Press, Norman. 